\title{
Effects of Sugar Crystals on Cerebrum
}

\section{Subham Kumari*}

Department of Dental Surgery, Buddha Institute of Dental Sciences and Hospital, Patna, India

*Corresponding Author: Subham Kumari, Department of Dental Surgery, Buddha Institute of Dental Sciences and Hospital, Patna, India.

DOI: 10.31080/ASDS.2020.04.0889
Received: July 09, 2020

Published: July 27, 2020

(C) All rights are reserved by Subham Kumari.

\section{Abstract}

Aim behind writing this article is to give powerful impact on the peoples mentality. Sugar is the generic name conferred to sweet tasting, a soluble carbohydrate.

Keywords: Monosaccharides; Disaccharides; Oligosaccharides

\section{Classification}

\begin{tabular}{|c|c|c|c|}
\hline & CARB & DRATES & \\
\hline$\downarrow$ & $\downarrow$ & $\downarrow$ & 7 \\
\hline $\begin{array}{l}\text { MONOSACCHARIDES } \\
\text { GLUCOSE } \\
\text { ת } \\
\text { FRUCCTOSE } \\
\pi \\
\text { GALACTOSE }\end{array}$ & $\begin{array}{l}\text { DISACCHARIDES } \\
\text { SUCROSE } \\
\text { R } \\
\text { LACTOSE } \\
\text { MAETOSE }\end{array}$ & $\begin{array}{l}\text { OLIGOSACCHARIDES } \\
\Omega \\
\text { RAFFINOSE } \\
\Omega \\
\text { STACCHYOSE }\end{array}$ & $\begin{array}{l}\text { POLYSACCHARIDES } \\
\nwarrow \Omega \\
\text { STARCH } \\
\text { GLỸCOGEN } \\
\Omega \\
\text { CELLULOSE }\end{array}$ \\
\hline
\end{tabular}

Figure 1

Positive impacts

- Consumption of food like bread, rice, potato, pata leads to metabolism of complex carbohydrates which ultimately breaks down in monosaccharides, mainly glucose normally two third of the glucose consumed is utilised by our brain

- $\quad$ Proopiomelanocortin and agouti related peptide neurons in hypothalamus sense central levels of glucose and regulates its metabolism.it thus travels via bloodstream to reach the brain capillaries where it undergoes astrocyte neuron lactate hypothesis
- Glucose according to this hypothesis is taken up from capillaries into the neurons and astrocytes, where in the neuron glucose undergoes glycolysis and pentose pathway to produce lactate and further pyruvate, which undergoes oxidation to produce acetyl COA and further ATP.

- This ATP stimulates the release of neurotransmitter glutamate.

- This glutamate is taken up by astrocytes in the brain which converts it into glutamine and gets reup taken by neurons.

- Glutamate is a powerful neurotransmitter which enhances memory and learning.

Negative impacts of sugar on cerebrum

- High blood glucose in the brain capillaries leading to over utilisation of glucose by astrocytes for a long time, causes activation of astrocytes.

- Activation of astrocytes leads to the production of pro in flammatory cytokines namely IL-1, IL-6 and tnf-alpha.

- Activation of such pro inflammatory cytokines over along period of tie leads to neuroinflammation and neuro degeneration. 
- $\quad$ Resulting in loss of memory, depression, anxiety, fever, lethargy, anhedonia and it even leads to progression of diseases like Alzheimer and diabetic encephalopathy [1-6].

\section{Bibliography}

1. Ahmed SH., et al. "Sugar addiction: pushing the drug- sugar analogy to the limit". Current Opinion in Clinical Nutrition and Metabolic Care 16.4 (2013): 434-439.

2. Nair SG., et al. "The Neuropharmacology of relapse to food Seeking: methodology ,main findings and Comparison with relapse to drug seeking". Progress in Neurobiology 89.1 (2009): 18-45.

3. Avena NM., et al. "Evidence for sugar addiction: behavioral and Neurochemical effects of intermittent excessive sugar intake". Neuroscience Biobehavior Review 32.1 (2008): 20-39.

4. Popkin BM and Nielsen SJ. The sweetening of the world's diet". Obesity Research 11.11 (2003): 1325-1332.

5. Shariff M., et al. "Neuronal nicotinic Acetylcholine Receptor Modulators Reduce Sugar intake". Plos One 11.3 (2016): e0150270.

6. Volkow ND., et al. "Imaging dopamine's role in drug abuse and addiction". Neuropharmacology 56 (2009): 3-8.

\section{Assets from publication with us}

- Prompt Acknowledgement after receiving the article

- Thorough Double blinded peer review

- Rapid Publication

- Issue of Publication Certificate

- High visibility of your Published work

Website: www.actascientific.com/

Submit Article: www.actascientific.com/submission.php

Email us: editor@actascientific.com

Contact us: +919182824667

Citation: Subham Kumari. "Effects of Sugar Crystals on Cerebrum". Acta Scientific Dental Sciences 4.8 (2020): 68-69. 